\title{
A Idolatria e o Papa Francisco: radicalidade na crítica ao capitalismo.
}

\author{
Allan da Silva Coelho*
}

\section{Resumo}

De que modo o papa Francisco incorpora em seus documentos pontifícios a categoria da idolatria na crítica social? Através de uma pesquisa bibliográfica e teórica, buscamos identificar o contexto em que a categoria se desenvolve na América Latina e passa a ser utilizada nos documentos do magistério. Se em um primeiro momento, João Paulo II utiliza a categoria com ressalvas e no contexto de crítica ao marxismo, Francisco utiliza o conceito em todo seu potencial crítico como em seu contexto de elaboração. Parece que a necessidade de coerência com o Concílio Vaticano II e a solidariedade às vítimas, na denúncia do conjunto de valores da sociedade atual, radicalizam o ponto de vista do papa atual permitindo aproximações com propostas teológicas que antes foram combatidas pela Santa Sé. Tal incorporação a seu quadro analítico amplia a radicalidade do anticapitalismo presente.

Palavras-chave: Idolatria; crítica ao capitalismo; Fetichismo; Papa Francisco. Capitalismo como religião.

\section{Idolatry and the Pope Francis: radicalism in the critique of capitalism}

\section{Abstract}

How does Pope Francis incorporate the category of idolatry in the papal documents in his critique of society? Through a bibliographical and theoretical research, referenced in the studies of the DEI School, we sought to identify the context in which the category develops in Latin America and is now used in the teaching documents. If at first John Paul II uses the category with reservations and in the context of criticism of Marxism, Francisco uses the concept in all its critical potential. It seems that the

* Licenciado em Filosofia, Doutor em Ciências da Religião, UMESP. Professor no PPGE da UNIMEP. E-mail: allan.filos@gmail.com . 
need for consistency with the Second Vatican Council and solidarity with the victims in denouncing the set of values of present-day society radicalizes the pope's point of view, allowing approximations with theological proposals that were previously opposed by the Holy See. This incorporation into his analytical framework expands the radicality of the present anti-capitalism.

Keywords: Idolatry; critical to capitalism; Fetishism; Pope Francis. Capitalism as religion.

\section{La Idolatría y el Papa Francisco: radicalidad en la crítica al capitalismo}

\section{Resumen}

¿De qué modo el Papa Francisco incorpora la categoría de la idolatría en los documentos pontificios en su crítica de la sociedad? A través de una investigación bibliográfica y teórica, referenciada en los estudios de la Escuela del DEI, buscamos identificar el contexto en que la categoría se desarrolla en América Latina y pasa a ser utilizada en los documentos del magisterio. Si en un primer momento, Juan Pablo II utiliza la categoría con salvedades y en el contexto de crítica al marxismo, Francisco utiliza el concepto en todo su potencial crítico. Parece que la necesidad de coherencia con el Concilio Vaticano II y la solidaridad a las víctimas, en la denuncia del conjunto de valores de la sociedad actual, radicalizan el punto de vista del Papa actual permitiendo aproximaciones con propuestas teológicas que antes fueron combatidas por la Santa Sede. Tal incorporación a su cuadro analítico amplía la radicalidad del anticapitalismo presente.

Palabras clave: Idolatría; crítica al capitalismo; fetichismo; Papa Francisco. Capitalismo como religión.

\section{Introdução}

É bem certo que Bergoglio foi eleito papa da Igreja Católica em um contexto de profunda crise interna da instituição eclesial. Mas não só a igreja, o clero ou o Estado do Vaticano são desafios ao papa eleito. Parece que todo o mundo conhece o aumento de tensões e desigualdades que com um breve olhar podem ser exemplificados como: a grande crise mundial dos migrantes e seus novos campos de concentração, conflitos armados oficializados pelas instituições internacionais ou a prática do terrorismo, a concentração gigantesca de riquezas, a escalada de governos autoritários com viés fascistas, a radicalização de princípios do neoliberalismo que questiona a legitimidade do dos direitos humanos fundamentais, além da catástrofe das mudanças climáticas... Neste contexto, o papa escolheu ser Francisco.

Desde o início de seu pontificado em 2013, Francisco encontrou turbulências e polêmicas. Não apenas parte da alta hierarquia cardinalícia não tem consenso frente a atuação do governo papal, como mesmo setores do mundo político, em especial aproximados à direita e à extrema-direita, também 
têm identificado em Francisco um ponto de inflexão na Igreja Católica e um problema a ser enfrentado. ${ }^{1}$

Tais polêmicas não são inocentes e ganham visibilidade especial frente às ações de forte caráter simbólico ou na publicação de documentos do magistério pontifical. Os seus principais textos oficiais receberam acusações ad intra ou ad extra. Por vezes, levaram setores a denunciar o papa como anticapitalista, antissitêmico ou comunista. Entretanto, esta chave de análise está em sintonia com as disputas pelo poder eclesial ou social, que poderiam ser traduzidas como profundo questionamento da legitimidade dos ensinamentos propostos por Bergoglio enquanto papa.

Uma outra abordagem interessante à esta questão, que se diferencia da anterior por corresponder a uma tentativa de compreender as fontes do pensamento do pontífice, tende a caracterizar o atual papado a partir de sua postura pessoal de austeridade, compromissado com os pobres, mas adversário da Teologia da libertação. Teriam temas em comum, mas pontos de referência diferentes e, talvez, antagônicos. Caberia à análise crítica compreender as diferenças entre a teologia de Bergoglio e as várias possibilidades de teologias latino-americanas. Entendo que se trata de uma questão que merece atenção, que se acrescenta elementos interpretativos, mas não tem como premissa central a contribuição para a transformação da sociedade. Nosso olhar neste estudo é associado a quem se interessa pelo modo como o fazer teologia, na América Latina ou em outras periferias do mundo, se associa com o pensamento crítico na tarefa história de superar a situação social que gera ou confirma uma realidade de opressão e exploração das vítimas.

Neste estudo pretendemos verificar de que modo o atual papa incorpora em seus documentos pontifícios a crítica à idolatria do mercado, um conceito da tradição teológica crítica da América latina. Há muitas questões decorrentes das formulações teóricas que Francisco produziu e/ou assinou e procuramos colaborar com a compreensão de uma delas. Há diversos elementos de continuidade e de novidade, que alguns

\footnotetext{
Barbie Latza Nadeau vem analisando a articulação de representantes da extrema direita mundial, como Steve Bannon e Matteo Salvini com setores conversadores católicos como o Cardeal Raymond Burke (NADEAU, 2018). Massimo Faggiolli também vem abordando o significado desta associação como importante resistência ao que representa o papa Francisco e sua abordagem teológico-pastoral (FAGGIOLLI, 2018). Recentemente a revista National Catholic Reporter dedicou seu editorial de 23/04/2019 para a mesma temática. Para as desconfianças dos setores políticos à esquerda, dedicamos um estudo que aborda parcialmente a questão (COELHO, 2018)
} 
estudos interessantes têm chamado de "continuidade descontínua"2. Neste artigo, escolhemos o tema da idolatria, procurando continuidades e descontinuidades de tradições específicas, não somente para tentar explicar os conflitos atuais em que Francisco toma parte, mas também para explicitar certas opções fundamentais e necessárias para um tipo de pensamento cristão que deseja combater radicalmente em defesa das vítimas. A categoria da idolatria, em sua compreensão associada ao fetichismo como elemento crítico do "capitalismo como religião", é uma contribuição do pensamento crítico latino americano.

Nesta perspectiva, nossa pesquisa analisa as encíclicas e exortações apostólicas de Francisco em busca da maneira como a crítica da idolatria foi incorporada no momento atual. Recuamos o olhar até os documentos de João Paulo II para proporcionar um ponto de comparação das diferentes maneiras de uso do conceito. Trabalhamos com a hipótese de que o uso de idolatria como crítica do fetichismo do capitalismo, como religião idolátrica, foi aprofundado e consagrado nos anos 1970 pela Teologia da libertação. Porém, no momento anterior a Francisco, seu uso estava deslocado como instrumento de crítica da própria Teologia da libertação. No entanto, certas escolhas do atual papa frente aos desafios globais levam a um reposicionamento no uso da categoria analítica "idolatria", assumida na plenitude de sua força crítica do capitalismo como religião perversa. Parece-nos que em busca de coerência com sua postura austera e seu compromisso com Concílio Vaticano $\mathrm{II}^{3}$, mas também procurando uma resposta articulada aos desafios globais, Francisco precisa enunciar respostar compatíveis com as dinâmicas dos sistemas que articulam a vida humana no mundo atual.

Seria esta postura que leva o papa a aproximar-se de categorias da visão social de mundo da chamada Escola do DEI, Departamento Ecumènico de Investigaciones, enquanto setor da Teologia da libertação que assumiu como central a articulação entre teoria do fetichismo e produção teológica. Esta delimitação permite aprofundar os elementos da constituição histórica do seu uso, mas não pretende compreender a realidade como fixa ou pouco dialética. Partimos da compreensão que as diversas maneiras de elaborar o pensamento teológico latino-americano estiveram em mútua fecundação e

2 Veja em CARRANZA, 2015.

3 Trabalhamos com a ideia de que mais do que um compromisso em resgatar os valores do Concílio Vaticano II, Francisco expressa como fonte oculta seu respeito pelo Pacto das Catacumbas (BEOZZO, 2015). Precisamos aprofundar esta possibilidade. 
que seus agentes circularam entre os diversos locus elaboraciones (cf. Dussel, 2012) de forma colaborativa.

Para refletir sobre isso, iniciamos apresentando os documentos delimitados para nossa pesquisa no magistério do papa Francisco. Em seguida, retomamos elementos da formulação da categoria analítica "idolatria" na tradição da Escola do DEI como uma das possibilidades da Teologia da libertação, com a especificidade de propor como central a articulação teologia e marxismo. Depois, recordamos o uso da "idolatria" nas encíclicas e exortações apostólicas do papa João Paulo II no contexto de suas opções teológicas e políticas. Por fim, como tarefa principal, procuramos traçar elementos para uma análise dos documentos no magistério de Francisco. Nas considerações, apresentamos outras possibilidades de estudos que permanecem como desafios para o campo que pretende aprofundar as relações críticas entre capitalismo e religião.

\section{Tradição e novidade na crítica ao capitalismo.}

Em especial no mundo moderno, a Igreja Católica recorre ao seu múnus de ensinar como um instrumento de combate nas disputas entre a verdade da fé e a realidade social. Os documentos eclesiais não se limitam a ensinar e orientar, mas se revelam modos de afirmação da autoridade da instituição católica. O magistério do papa é compreendido como a palavra da instituição, por vezes, única palavra autorizada e critério de fidelidade à pertença eclesial. Desde os séculos XVIII e XIX os documentos pontificais tornaram-se expediente central nas disputas dos projetos de sociedade da alta cúpula da hierarquia católica.

Todo documento eclesial, por sua lógica, pretende apresentar algo novo, seja para complementar ou para aprofundar questões que teriam relevância no grupo social a que se destina. No entanto, toda atualização (aggiornamento) ou renovação na Igreja Católica pressupõe a disputa de legitimidade na reivindicação de uma certa tradição, isto é, mesmo para propor mudanças é preciso que sejam compreendidas em relação à alguma continuidade da tradição. Com Francisco não é diferente e toda a novidade de seu pontificado é apresentada como retorno à Tradição em seu sentido amplo de conjunto de elementos transmitidos pela sucessão apostólica. Como disse Passos,

(...) toda plataforma renovadora exige um discurso legitimador capaz de justificar e direcionar as mudanças pretendidas, sem o que prevaleceria a 
cisão institucional, ainda mais em se tratando de uma instituição de dinâmica tradicional como a Igreja católica. Nesta, um novo paradigma só é legítimo se ancorado na longa tradição: o novo deve ser buscado no meio do antigo, jamais como um paradigma renovador, puro, que nega ou dispensa o anterior (2017).

Desse modo, a novidade precisa ser legitimada por algum elemento da Tradição. No caso de Francisco, articula como elementos desta continuidade o olhar para os pobres e a centralidade da misericórdia no anúncio do Evangelho. Para o uso da categoria idolatria encontra-se a mesma condição. A renovação do seu sentido deve estar associada a elementos da Tradição. Na América Latina, a partir dos anos 1970 seu sentido foi ancorado fortemente na leitura profética da Bíblia, mas também da busca de seu sentido na história da igreja.

Se considerarmos que a temática da idolatria na crítica da sociedade foi amplamente trabalhada desde a América Latina, em qual sentido seu emprego pode ser considerado como renovação do magistério? Sung afirma que "a crítica teológica à idolatria que ocorre no capitalismo atual foi assumida também pelo papa Francisco" (2016, p.31). Para verificar e refletir a caracterização desta renovação que a incorporação de tal categoria proporciona na doutrina pontifical católica, propomos analisar os textos de Francisco mais de perto, destacando temas que podem ser aprofundados. $\mathrm{O}$ exercício de retornar aos textos de João Paulo II em busca do uso da mesma categoria permite entender o grande deslocamento na maneira como o termo passa a ser utilizado, em especial na tensão com a teologia na América Latina.

A primeira encíclica de Francisco é a Lumem Fidei (29/06/2013) que é um documento preparado pelo papa Bento XVI para a conclusão do Ano da Fé. Praticamente todo o texto expressa a teologia do papa que renunciou, mas publicado pelo sucessor, completando a trilogia de Bento XVI sobre a esperança, a caridade e, agora, a fé. A Exortação Apostólica Evangelii Gaudium (24/11/2013) é um documento feito a partir das conclusões do Sínodo dos Bispos de 2012 sobre a evangelização. Francisco apresenta amplamente sua concepção de pastoral neste documento. Diversos economistas e agentes políticos, de direita ou de esquerda, polemizaram com este documento com vocação pastoral, na qual defende o programa da Igreja em saída. Concordamos com Passos, para quem

A Igreja em saída não foi apenas um slogan do pontificado ou o eixo da exortação apostólica sobre a evangelização. Tem sido, de fato, a base programática do pontificado, com impactos renovadores em todas as dimensões e ações da Igreja: na pastoral, na moral, na teologia e no próprio papado (2017). 
A primeira Encíclica exclusiva de Francisco é a Laudato Si (24/05/2015), na qual eleva as preocupações com o cuidado da Casa Comum ao nível máximo do magistério pontifício, convocando a cada um, fiel cristão ou não, a uma profunda transformação no comportamento para salvaguardar o futuro do planeta. Essa encíclica também foi duramente questionada pelos agentes externos à Cúria, seja por seu forte caráter antissistêmico, seja pelo tom de urgência de ação4.

Após a conclusão em 2015 do Sínodo dos Bispos sobre a família, o papa publica a Exortação Apostólica Amoris Laetitia (19/03/2016) que, por sua vez, provocou profunda celeuma entre os setores mais conservadores da Igreja Católica ao colocar o princípio da misericórdia como critério de análise da diversidade de situações pastorais sobre a família. É contra argumentos deste documento que um grupo de cardeais, bem como de leigos, colocou objeções diretamente a Francisco. Divulgada em abril de 2018, a Exortação Apostólica Gaudete et Exsultate é um documento pontifício sobre a santidade no mundo, no qual Francisco reflete e propõe uma visão bastante diferente dos exercícios tradicionais da espiritualidade cristã, como diretriz para todos os cristãos, clérigos ou leigos, para viver o cristianismo na contra-corrente da cultura de consumo. Ainda devem ser publicados documentos conclusivos em referência ao Sínodo sobre a juventude (outubro de 2018) e o Sínodo sobre a Amazônia (outubro de 2019). Este último, é esperado como possível aplicação da Encíclica Laudato Sí, buscando entender a missão da igreja nesta região, refletir sobre os caminhos para uma ecologia integral e a denúncia dos interesses das corporações que colocam seus interesses acima da vida das pessoas, dos povos e do planeta ${ }^{6}$. Enfim, vários documentos de Francisco conheceram de algum nível de polêmica e debates.

Entre os temas debatidos nestas polêmicas, um interessa em especial a este estudo que seria a ideia de que a crítica anticapitalista de Francisco não seria um retorno a um pauperismo medieval, mas simples continuidade lógica

\footnotetext{
Cf.: LÖWY, 2017.

A Exortação Apostólica pós-sinodal Christus Vivit foi publicada em 25/03/2019 e não entrou no escopo dos documentos então analisados em nosso estudo.

6 Em razão do Sínodo da Amazônia, o governo do Brasil mobilizou seu Gabinete de Segurança Institucional em preocupação com o que considera intervenção externa em assuntos de soberania nacional. Veja, por exemplo: https://noticias.uol.com.br/politica/ ultimas-noticias/2019/02/12/quem-cuida-da-amazonia-brasileira-e-o-brasil-diz-helenosobre-sinodo.htm Acesso em 20/03/2019.
} 
do movimento de deslocamento da igreja iniciado em João Paulo II $^{7}$. Entre os que argumentam neste sentido, o historiador Stefanoni (2015) que quem mudou foi a conjuntura histórica e não necessariamente a posição do Vaticano ou do ocupante da função de papa. Desse modo, Stefanoni indica que na medida em que o neoliberalismo vai se tornando hegemônico na orientação ideológica do mundo globalizado, a igreja se aproximaria dos movimentos sociais no divisor comum do antineoliberalismo. $\mathrm{O}$ antineoliberalismo não representaria uma novidade ou mudança, mas uma convergência conjuntural em que a igreja expressaria de outra maneira a antiga postura católica de tentar orientar moralmente a economia de mercado em vistas da humanização do capitalismo.

Stefanoni acompanha o argumento de Semán, para quem o papa João Paulo II teria reorientado sua posição política e ideológica após a queda da União Soviética e do chamado socialismo real. O comunismo, deixando de ser uma ameaça real, também deixaria de ser o principal adversário do magistério católico. Em um mundo globalizado hegemonicamente capitalista neoliberal, o principal desafio seria a igreja exercer seu papel de guia moral e ético para os perigos dos exageros das puras leis do mercado. Esta tarefa seria uma tentativa do catolicismo manter alguma relevância para "as maiorias que são a massa de manobra do capitalismo" (STEFANONI, 2015). Decorre da leitura de Stefanoni que a Igreja Católica teria minimizado as críticas ao capitalismo frente a um problema maior, que seria o risco de perder a classe trabalhadora para um tipo de comunismo ateu. Por isso, após o fim da URSS e com a queda do muro de Berlim, mesmo João Paulo II poderia modificar aspectos de seu discurso. Francisco seria sua continuidade com mais forte linguagem convocatória de mobilização visando, principalmente, manter a relevância e o poder católico no mundo moderno, concedendo à estrutura institucional alguma credibilidade.

Em outra perspectiva, Bento (2018) defende que Francisco modifica realmente sua compreensão da realidade para além das tradicionais posturas reformistas que a Doutrina Social da Igreja defendeu em sua história, desde

\footnotetext{
Michael Löwy tem diversos estudos nos quais defende que haveria uma "afinidade negativa" do catolicismo com o capitalismo. O conceito provém de uma quase dedução lógica da afinidade weberiana entre protestantismo e ethos capitalista. Löwy defende que a rejeição ética da cultura católica frente aos valores frios do sistema social capitalista nunca teria desaparecido, permanecendo de algum modo tanto no conservadorismo católico, como nas teologias progressistas. Neste sentido, a afinidade negativa seria uma rejeição ética fundamental que fundamenta alguns aspectos de uma tradição católica anticapitalista. Como exemplo: LÖWY 1989, 1990, 1991, 1996, 1999, 2000, 2016. Veja-se também SOFIATI, CAMILO e COELHO, (2018).
} 
a Rerum Novarum (1891), assumindo um claro viés antissistêmico, portanto, anticapitalista. Segundo Bento, a principal ruptura seria com a crença de que haveria possibilidade de corrigir os erros do capitalismo e que esta aposta seria a melhor escolha possível aos católicos (BENTO, 2018, p.510). Bento avalia os discursos do papa Francisco nos encontros com movimentos sociais e populares e percebemos que outra inflexão que seria a centralidade da base na constituição de projetos de sociedade, aspecto que não estaria dissociado da proposta do papa para a transformação da igreja.

A leitura que propomos não é incoerente com estes argumentos, mas é diferente por apontar uma dimensão teológica que tem consequências nas apostas políticas, sem serem exclusivamente políticas. Se não discordamos de boa parte do raciocínio de Stefanoni, nossa pesquisa parece concordar mais plenamente com o argumento de Bento. Haveria de fato uma mudança substantiva na visão social de mundo ${ }^{8}$ de Francisco. Ao inserir a temática teológica da idolatria, em sua concepção radical como elaborada na teologia latino-americana, Francisco modifica todo seu quadro de referência de análise da sociedade. Se o capitalismo é idólatra, o caminho seria sua superação, instituindo novas apostas pastorais, novos elementos da crítica social e, também, novos aliados ao catolicismo.

Ao optar pelos pobres sob o neoliberalismo, na sensibilidade do Concílio Vaticano II, descobre que parte do Povo de Deus é vítima da injustiça. A ideia de vítima, categoria central na Teologia da libertação, revela a relação da injustiça social com uma estrutura sacrificial teológica. As categorias de idolatria e vítima associadas, no contexto em que Francisco canoniza Dom Oscar Romero indica com maior clareza a continuidade com outra tradição sempre presente nos últimos anos, mas, na verdade, combatida pelo Vaticano sob João Paulo II. Assumindo o papel de um "Grande Reformador", no imaginário de São Francisco (reconstruir a igreja no testemunho evangélico junto aos pobres), não permite ignorar que simbolicamente o atual papa vai além dos seus antecessores diretos, colocando em destaque um conjunto teológico-eclesial que sobreviveu na resistência. Propõe superar o rigor doutrinal, que passa a ser combatido como um erro grave. Frente a lei, temos a prática da caridade. O amor como experiência fundamental. A vida do pobre como critério. A seguir, vamos situar a categoria de idolatria nesta tradição teológica.

8 Utilizamos o conceito e a estrutura de compreensão da "visão social de mundo" como proposta por Lucien Goldmann. (GOLDMANN, 1959; LÖWY, 2001; LÖWY e SAIR, 2008). 


\section{A idolatria como categoria analítica}

Nos anos 1970, os cristãos engajados foram perseguidos, exilados ou mortos em vários contextos na América Latina. O compromisso com a transformação social, as frentes de luta e aprofundamento teórico do pensamento crítico levaram os cristãos de libertação (LÖWY, 2016) a dividir diversas trincheiras com os militantes socialistas e marxistas. O tema da idolatria foi incorporado às reflexões teológicas a partir do intercâmbio entre setores da teologia da libertação, cientistas sociais e economistas marxistas, a partir dos "seminários de pesquisadores" realizados por iniciativa dos teólogos da libertação que se organizavam a partir do DEI, Departamento Ecuménico de Investigaciones, instalado nos anos 1970 na Costa Rica (COELHO, 2014).

No grupo em torno ao DEI, a experiência do exílio, o diálogo com diferentes cientistas sociais, a perspectiva ecumênica e a partilha de problemas e expectativas com os movimentos sociais e revolucionários, permitiram a gestação de uma abordagem crítica que expressa um dos fortes sentidos da famosa Tese I sobre o conceito de história de Benjamin. ${ }^{9}$ Destacamos aqui alguns elementos que expressam parte do acúmulo teórico e do diálogo sério com categorias fundamentais do marxismo, como a teoria do fetichismo. ${ }^{10}$ Hinkelammert (1983) desenvolve a crítica do fetichismo do dinheiro, do mercado e do capital propondo sua importância teológica na crítica radical do capitalismo. Os debates desta relação entre fetichismo e defesa da vida no cristianismo levou diversas outras produções acadêmicas associando o fetichismo e a idolatria. Richard afirma que na crítica do capitalismo

Tratamos parcialmente desta relação em nossa tese doutoral Capitalismo como religião (COELHO, 2014). A tese referida e uma proposta de sua leitura se encontra em LÖWY, 2005.

10 Neste texto destacamos em meio as obras produzidas em torno ao DEI três obras de referência para o momento de constituição da categoria em questão. A primeira, um livro de Franz Hinkelammert que no Brasil foi publicado em 1983 com o título "As armas ideológicas da morte", obra em que temos um profundo estudo sobre as relações entre o fetichismo em Marx e a defesa da vida na tradição judaico-cristã. Este texto foi a base de um seminário de estudos no DEI do qual se originou uma obra coletiva, publicada no Brasil em 1982 com o título "A luta dos deuses: os ídolos da opressão e a busca do Deus libertador". Neste livro temos diferentes possibilidades de abordagem metodológica do tema idolatria-fetichismo e serviu de inspiração para outros trabalhos. O terceiro livro de referência que destaco é a obra de Hugo Assmann e Franz Hinkelammert intitulada “A idolatria do mercado", obra que não apenas sintetiza o profundo debate até então realizado, como estabelece marcos de um programa de pesquisa a ser desenvolvido. 
o problema central está na idolatria, como culto aos falsos deuses do sistema de opressão. Mais trágico que o ateísmo é o problema da fé e da esperança nos falsos deuses do sistema. Todo sistema de opressão caracteriza-se precisamente por criar deuses e gerar ídolos sacralizadores da opressão e da antivida (1982, p.07).

Richard denuncia que "em um mundo oprimido, a evangelização deve chocar-se fundamentalmente com a idolatria... o mundo opressor é um mundo de fetiches, ídolos, sacerdotes e teólogos" (RICHARD, 1982, p.09). As reflexões deste setor da teologia da libertação que incorporou como centrais as categorias marxistas no fazer de seu trabalho, avançou na consolidação de categorias analíticas como a ideia de "idolatria do mercado". Sung (1998a) defende que esta categoria é uma importante chave de leitura para o capitalismo, que oculta em sua estrutura uma visão sacrificial sob linguagem secularizada. Para ele,

o segredo do sagrado-sacrifício reside na polaridade do fascínio e temor que lhe dá a capacidade de inverter o bem e o mal. Violência, sofrimento e morte são sempre vistos como males a ser combatidos. Mas, quando uma forma específica de violência, sofrimento e morte é apresentada como uma exigência do sagrado, como uma violência 'purificadora e redentora' que manifesta o próprio sagrado, esta deixa de ser mal e se transforma em um bem (SUNG, 1998a, p.124).

Quando os sacrifícios em nome da realização da promessa do sistema econômico são compreendidos como sacrifícios necessários para a plena realização da sociedade humana, tornam-se aceitáveis, fascinantes, completando a inversão de ações com resultados eticamente condenáveis como se fossem um bem. A síntese desta lógica perversa que "desvela a dinâmica misteriosa que se dá em torno e a partir da sacralização do mercado é o conceito de idolatria, um conceito de origem teológica" (SUNG, 1998a, p.125). Tal conceito encontrou formulação impactante na obra de Assmann e Hinkelammert (1987):

ídolos são os deuses da opressão. Biblicamente, o conceito de ídolos e idolatria está diretamente vinculado à manipulação de símbolos religiosos para criar sujeições, legitimar opressões e apoiar poderes dominadores na organização do convívio humano (1987, p.11). 
Um dos elementos da idolatria do mercado consiste em formular uma "teologia intrínseca e endógena" (ASSMANN; HINKELAMMERT, 1987, p.254). Esta denúncia permite a reflexão teológica como discernimento das imagens de deuses com ídolos. De acordo com Sung, permite "o desvelamento do fascínio dos sistemas idolátricos e o da inversão sacrifical que inocenta os que vitimam e culpabiliza a vítimas dos sistemas sacrificiais" (1998a, p.129). Afirmar que um ídolo é um deus falso não significa dizer que tais deuses não tenham poder. A característica da fetichização que configura a idolatria é justamente em conceder um poder sobre-humano para algo que é resultado das ações humanas e impõe condições para a vida e a morte. A partir do momento em que certas sociedades se sujeitam aos princípios idolátricos que exigem sacrifícios como condições necessárias para a realização, os ídolos matam efetivamente. Dussel argumentará que, em sua opinião, idolatria e fetichismo compreendem de duas maneiras a mesma relação (1977).

Justamente o potencial explosivo destas análises está na conjugação articulada para a radical crítica do capitalismo de uma tradição profética de raízes judaico-cristã, com a corrente revolucionária marxista. A esta junção, some-se elementos da crítica romântica e das análises weberianos, como indicadas nos estudos sobre o "capitalismo como religião" (COELHO, 2014). Temos aqui, portanto, um fazer teologia que reconhece relações profundas da teoria do fetiche de Marx e a análise do espírito do capitalismo da tradição weberiana.

É importante ressaltar que este não foi o único modo de se fazer teologia da libertação. O teólogo Antonio Manzatto (2015), no primeiro ano do pontificado de Francisco, pergunta-se se a Teologia da libertação estaria agora oficializada. Em seu ponto de vista, ela teria sido criticada pelo Vaticano nos anos 1980, mas, no entanto, nunca oficialmente condenada. Destaca que o elemento comum deste fazer teológico é colocar a opção pelos pobres como chave hermenêutica através da qual se lê toda a revelação de Deus. Diferencia entre a diversidade de métodos da teologia da libertação, um setor que privilegiou relações com o marxismo, em especial como instrumental de análise da sociedade (primeira mediação, o ver). Diz Manzatto:

Preocupada com os pobres do continente em processo de conquista de sua libertação, a Teologia da Libertação fez apelo às ciências do social para melhor conhecer os mecanismos de opressão e dominação. O aparato marxista de crítica social ao capitalismo pode ser descoberto e utilizado por teólogos que, em um primeiro momento, não viam perigos nesta utilização meramente 
instrumental de categorias marxistas. Assim houve uma grande aproximação entre os envolvidos com a teologia da libertação e os movimentos socialistas e marxistas sem que com isso necessariamente se abrisse mão da perspectiva teológica da reflexão que era feita (MANZATTO, 2015, p.186).

A construção do raciocínio indica que, se em um "primeiro momento" teólogos não "viam perigos" no uso "meramente instrumental" das categorias marxistas, é possível que poderiam haver perigos nesta relação. Manzatto aponta em nota de rodapé os debates sobre diferentes concepções do método da Teologia da libertação. Se por um lado, autores como Clodovis Boff entendem que todas as mediações da elaboração da teologia da libertação estariam interligadas, Libânio entendia que a teologia "começa" no segundo momento, após a mediação sócio analítica (MANZATTO, 2015, p.187). Esta distinção permitiria afastar-se mais facilmente do método marxista, quando necessário. Por outro lado, o autor ressalta que a preferência pelos pobres foi apontada em alguns momentos como luta de classes em perspectiva marxista. Para exemplificar, indica justamente Richard e a obra coletiva $A$ Luta dos Deuses (1982). Complementa ainda sugerindo os estudos de Michael Löwy sobre o cristianismo de libertação e o marxismo. Neste sentido, concordamos justamente com esta diferenciação realizada por Manzatto, ressaltando que essa articulação é central na proposta teológica da chamada "Escola do DEI" (evidentemente, como este grupo não era hermético, isto não se aplica a todos os teólogos e teólogas que participaram ou dialogaram com seus referenciais).

Manzatto aponta que o eixo central da opção pelos pobres, por vezes foi duramente combatido pelo Vaticano, mas acabou incorporado no magistério pontifical, diferente da aproximação com o marxismo. Haveria, na instrução Libertatis Nuntius (06/08/1984) a clara condenação do uso de categorias marxistas, a recusa a referência à luta de classes e a acusação de confusão entre libertação social e salvação transcendental. Esta primeira instrução encontrou forte resistência não apenas entre teólogos, mas também de amplos setores do episcopado latino-americano. Lembramos que é o momento histórico do processo da Santa Sé contra Leonardo Boff, que defendido por grandes cardeais brasileiros, acabou punido com um ano de silêncio penitencial e emitindo um esclarecimento no qual diz: "declaro que não sou marxista” (MNDH, s/d, p.149).

De fato, vários teólogos não se reconheceram no documento do Vaticano, mas, entre equívocos e acertos teóricos sobre o marxismo na referida 
instrução, atingia plenamente outros setores. Manzatto afirma que se a instrução de 1984 foi muito ácida, a nova instrução, Libertatis Conscientia (22/03/1986) seria "mais branda" e avalia de forma positiva o resultado das instruções pois teriam permitido à Teologia da libertação "um quadro referencial de segurança" e o afastamento da utilização de categorias marxistas (MANZATTO, 2015, p.193 $)^{11}$. Nossa avaliação, com um período maior de desenvolvimento do pontificado de Francisco, é que esta questão deixa de ser central e encontra uma nova formulação, como indicaremos mais adiante. Aqui, interessa ainda concordar com a avaliação do autor que o papa atual incorpora as categorias do pobre, da periferia e do valor da religiosidade popular. "Francisco conhece, e bem, os desdobramentos político-sociais da opção preferencial pelos pobres." (MANZATTO, 2015, p.198). Prioriza a prática pastoral e aceita o método verjulgar-agir, tendo expressado estes elementos no Documento de Aparecida, do qual Bergoglio foi um dos principais redatores. Estas características, segundo Manzatto, estão presentes também na Evangelii Gaudium. Caberia refletir se a leitura dos documentos pontifícios não permite dizer que, para Francisco, a proximidade ou não com categorias marxistas estão minimizadas enquanto problema frente as ameaças do capitalismo sobre a humanidade.

\section{Uso da categoria idolatria em João Paulo II}

Como dissemos, Sung (2016) considera que nos documentos e discursos de Francisco a crítica teológica à idolatria foi assumida pelo Vaticano. Se parece que esta categoria analítica é conhecida desde o período de sua elaboração, nos anos 1970-1980, entretanto deve ter sido considerada perigosa pela cúpula da Igreja Católica. Podemos ver que, além das referidas instruções sobre a Teologia da libertação dos anos 1980, a partir de então, o tema da crítica aos efeitos negativos da economia capitalista pode ser cirurgicamente pinçado nos documentos do papa João Paulo II. Mesmo a categoria idolatria aplicada à economia aparece algumas vezes, em quatro ocasiões a partir de $1987^{12}$. Entretanto, João Paulo II nunca utiliza deste instrumental teórico com a mesma finalidade para o qual foi cunhado pelos teólogos latino-americanos. Nossa hipótese é que em Francisco a leitura é outra, que permite incorporar plenamente a lógica da idolatria do mercado.

\footnotetext{
11 Seria interessante comparar esta avaliação, de quem não se viu atingido pelas instruções, com a de teólogos que foram perseguidos, condenados e combatidos pelo Vaticano neste período.

12 A categoria apareceu em documentos de 1987, 1991, 1996 e 1999.
} 
Um primeiro exemplo, quando João Paulo II faz uma histórica visita à Cuba, em 1998, critica o neoliberalismo por confiar nas "forças cegas do mercado". A explicitação desta crítica aparece logo depois na Exortação Apostólica Ecclesia in America (1999), na qual, em dois parágrafos de contextos diferentes, analisa o processo de globalização. Diferenciando-a entre seus aspectos comunicacional, econômico e cultural, o documento apresenta a dimensão comunicacional como geralmente positiva. A dimensão cultural, aparece como negativa, por ter como consequência a modificação dos valores cristãos.

O destaque do parágrafo é para a globalização econômica que tem consequências positivas, destacando valores defendidos com empenho pelos defensores do sistema, como a eficiência, o aumento da produção constituindo-se um verdadeiro serviço às famílias. Porém, acrescenta que podem vir a ter consequências negativas se "dirigida por puras leis do mercado". A lista destas consequências foi realista: atribui valor absoluto à economia, aumenta o desemprego, deteriora os serviços públicos, destrói o meio ambiente, aumenta diferença entre ricos e pobres, impõe uma concorrência injusta (EA, 20). A conclusão é que a igreja, preocupada, reivindica tutoria ética sobre a economia capitalista. Um dos aspectos constantes é a tentativa do controle moral sobre a economia, a partir da missa ética que a igreja se propõe como fundamento da realidade. Trata-se de uma escolha de um tipo de sociedade capitalista.

Mais ao final da Ecclesia in America, temos outra passagem crítica, agora destinada a analisar o neoliberalismo, em que João Paulo II diz:

Domina cada vez mais, em muitos Países americanos, um sistema conhecido como « neo-liberalismo »; sistema este que, apoiado numa concepção economicista do homem, considera o lucro e as leis de mercado como parâmetros absolutos a prejuízo da dignidade e do respeito da pessoa e do povo. Por vezes, este sistema transformou-se numa justificação ideológica de algumas atitudes e modos de agir no campo social e político que provocam a marginalização dos mais fracos. De fato, os pobres são sempre mais numerosos, vítimas de determinadas políticas e estruturas frequentemente injustas (EA, 55).

Nesta passagem, temos alguns elementos considerados tradicionais do anticapitalismo católico, como a crítica ao lucro e o aumento da pobreza, mas também dialoga com a perspectiva da absolutização da economia frente 
a dignidade dos seres humanos. A solução proposta não questiona o sistema capitalista, mas propõe promover mais solidariedade, o Estado de Direito e educação cívica para a ordem e a paz. É interessante perceber, por um lado, que este documento é resultado do Sínodo dos bispos do continente americano, em que evidentemente o tema da crítica teológica à economia constituía-se um eixo central das análises eclesiais. Por exemplo, a imensa maioria dos documentos da Conferência Nacional dos Bispos do Brasil, a CNBB, explicitam com detalhes esta análise (COELHO, 2006). Por outro lado, nenhuma outra exortação resultante dos Sínodos de outros continentes incorporou nenhuma menção ao tema.

João Paulo II, ao menos em três documentos do magistério pontifício fez uso da categoria idolatria explicitamente. Em um deles, na encíclica Socillicitudo Rei Socialis (30/12/1987), na qual celebra os 20 anos da encíclica Populorum Progressio, de Paulo VI, o papa critica a idolatria do dinheiro, mas desloca seu conteúdo ao criticar na mesma frase a idolatria da ideologia, da classe e da tecnologia (SRS, 37). Deste modo, a noção desliza de uma crítica anticapitalista para uma crítica de todas as formas de absolutização, incluindo as da ideologia e da classe social. Arremata o parágrafo na reflexão sobre o capitalismo liberal, mas com forte condenação do "coletivismo marxista".

É interessante notar que na encíclica que celebra os cem anos da Rerum Novarum, a encíclica Centesimus annus (01/05/1991), João Paulo II utiliza a categoria da "idolatria" do mercado de forma mais próxima de seu contexto de elaboração, mas com aspas no termo idolatria, expressando seu uso deslocado do tradicional. Esta breve passagem, que aponta riscos para o "novo capitalismo", não deixa de registrar os elogios aos mecanismos do mercado como "seguras vantagens" (CA, 40). No entanto, a crítica severa do documento, no longo parágrafo seguinte mais uma vez é ao marxismo, que teria criticado a reificação e a alienação a partir de valores equivocados. Em 1991, o pressuposto do texto do papa é a falência do socialismo e a superação das análises de Marx. Por fim, destacamos que na exortação apostólica Vita Consecrata $^{13}$ (25/03/1996), analisando as qualidades da vida que se consagra à pobreza evangélica, João Paulo II afirma-a como um valor que "contesta vigorosamente a idolatria do dinheiro, propondo-se como apelo profético lançado a uma sociedade que, em tantos lugares do mundo abastado, se arrisca a perder o sentido da medida e o próprio significado das coisas" (VC, 90).

13 Exortação dedicada à vida religiosa consagrada no âmbito da Igreja Católica. 
Se em João Paulo II o conhecimento da categoria que analisamos vai aparecendo de forma indireta, primeiro deslocando-a, depois reconhecendo-a como um risco possível, até identificar o seu valor profético, podemos concordar que esta transição do uso acompanha o cenário político mundial em que, com o colapso do "socialismo real" no Leste Europeu e Ásia, tais críticas poderiam ser compreendidas em novo contexto. Durante o pontificado de Bento XVI, entre abril de 2005 e fevereiro de $2013^{14}$, a idolatria do mercado não apareceu em nenhuma encíclica ou exortação apostólica, o que exigiria um estudo mais detalhado de sua ausência. Isto não prejudica a comparação com o uso da categoria nos documentos do papa Francisco, em especial a partir de seu segundo documento, o primeiro escrito por ele mesmo.

\section{Francisco e o uso de idolatria}

Os documentos do papa Francisco utilizam o conceito de idolatria e a sua temática entorno abundantemente. ${ }^{15}$ Ele aborda a crítica ao dinheiro e à ambição como fundamento da vida, a absolutização do mercado e do eficientismo como confiança equivocada nas coisas criadas pelos seres humanos, acusados de neopelagianismo. O conjunto dos documentos esboçam uma denúncia geral de um estilo de vida consumista e descartável. A vida dos pobres, espoliada e vitimada, é o critério de julgamento sobre esta civilização. Indica o esgotamento do capitalismo e a urgente necessidade de uma outra forma de viver. Vejamos com maiores detalhes em cada um dos documentos citados.

\section{a. Lumem fidei}

A encíclica Lumem fidei é um documento raro, escrita por Bento XVI para completar documentos pontifícios sobre as virtudes da caridade, da esperança e da fé, foi assumido por Francisco depois da renúncia do antecedente. $\mathrm{O}$ atual pontífice diz que acrescentou algumas contribuições ao texto, mas o uso do conceito de idolatria parece ser do original de Ratzinger. Aparece concentrado em um único parágrafo do texto, o número 13, em que trata da "fé verdadeira" e a tentação da incredulidade, como idolatria. O tema da idolatria surge com sua força crítica da tradição judaica, nos ensinamentos

\footnotetext{
14 Em seu pontificado, Bento XVI publicou quatro exortações apostólicas e três cartas encíclicas.

15 Este motivo nos leva a uma seção um tanto desproporcional em relação aos outros itens abordados neste estudo.
} 
rabínicos tendo referência no filósofo Martin Buber, para quem há idolatria "quando um rosto se dirige reverente a um rosto que não é rosto" (LF, 13). É uma categoria crítica, pois exige discernimento. Reverencia-se um rosto que não é, pois é coisa, obra das próprias mãos. Uma diferença entre ídolos e o Deus verdadeiro.

Assim, ídolos não provocam e nem convocam, não exigem conversão, pois “tem boca, mas não falam” (S1 115, 5). Neste sentido, a idolatria é o contrário da fé, que "é separação dos ídolos para voltar ao Deus vivo, através de um encontro pessoal” (LF, 13). A dimensão pessoal da fé em oposição à idolatria é destacada no texto pelo caráter do encontro pessoal com o rosto de Deus, como Deus verdadeiro. Esta é uma questão importante na tradição da Escola do DEI, bem formulada nos escritos de Dussel ${ }^{16}$, em que a relação face a face, de reconhecimento do rosto do outro, sintetiza e expressa a complexidade de relações dos humanos. Os seres humanos podem se relacionar com algo que é coisa, mas trata-lo como objeto de reverência e, por outro, diante de um alguém, um rosto de outro homem/humano, comumente pode ser considerado como coisa, objeto ou algo que faz parte do funcionamento do sistema, sem mistério ou transcendência. Parece que a passagem de Lumem Fidei expressa a relação entre rosto divino que provoca conversão pessoal e reverência frente ao encontro (falso) com ídolos com os quais se ocupa o locus de Deus.

No entanto, o tema da idolatria retorna no item número 57 , já no final da encíclica, agora como denúncia dos "ídolos do mundo". É uma aplicação sutilmente diferente da primeira, com um contexto bem demarcado: é frente a realidade dos que sofrem. O documento afirma que a luz da fé não apaga nem faz esquecer os sofrimentos. Os sofredores de cada época, como foram os pobres para Teresa de Calcutá, são mediadores de luz, que guiam os passos na noite, mesmo que não dissipem as trevas. A fé, mediada como luz pelos que sofrem, é suficiente para continuar a caminhar. Associada à caridade e à esperança, projeta um "futuro certo, que se coloca numa perspectiva diferente relativamente às propostas ilusórias dos ídolos do mundo, mas que dá novo impulso e nova força à vida de todos os dias" (LF, 57). Complementa com um apela para que "não deixemos que nos roubem a esperança..." que aparecerá novamente na encíclica Evangelii Gaudium (EG, 86). É certo que o discernimento dos ídolos do mundo a partir dos que sofrem inscreve-se

16 Por exemplo: DUSSEL, 1994 ou 2012. 
na tradição da Teologia latino-americana, como crítica às teodiceias vigentes (COELHO, 2017).

\section{b. Evangelii Gaudium}

No segundo documento, a exortação Evangelii Gaudium, a crítica à "idolatria do dinheiro" é um elemento central. Há uma toda uma parte dedicada a refletir sobre o papel do dinheiro como uma nova forma de dominação sobre as pessoas e a coletividade, mas também é um eixo estruturante de todo o texto da encíclica. A categoria idolatria que nomina uma parte corresponde exatamente ao conteúdo elaborado na Teologia da libertação, associado à tradição bíblica, mas também à teoria do fetichismo (EG, 55) e às críticas à absolutização do mercado (explicitamente EG, 56).

A criação de novos ídolos é compreendida a partir de certa compreensão antropológica, que tem como critério referencial a primazia do ser humano. As questões econômicas devem ser entendidas nesta referência: a negação da primazia do ser humano ou a redução da vida humana a uma de suas características produz desequilíbrios e crises mais complexas e profundas. Se antes tal negação levou à adoração do "antigo bezerro de ouro", hoje encontra uma "nova e cruel versão no fetichismo do dinheiro e na ditadura duma economia sem rosto e sem um objetivo verdadeiramente humano" (EG, 55).

Esta economia do fetiche é caracterizada utilizando todo o arsenal de críticas que conhecemos na teologia da libertação. A absolutização do mercado retira da vida humana a condição de parâmetro supremo. Critica o modo como o mercado divinizado é transformado em regra absoluta e o mecanismo que funciona como impessoalidade sem rosto, mas rege de fato a vida humana. Francisco prega que não se pode "confiar nas forças cegas e na mão invisível do mercado" e, ainda, acusa as soluções econômicas apresentadas como remédios mas se constituem como "um novo veneno, como quando se pretende aumentar a rentabilidade reduzindo o mercado de trabalho e criando assim novos excluídos" (EG, 204).

Este processo explicita como valores a competitividade e a lei do mais forte (ex. EG, 53), a meritocracia (EG, 209), a indiferença (EG, 54 ou 272), o individualismo e o consumismo. Tal conjunto de contra-valores opera articuladamente. $\mathrm{Na}$ indiferença, a "vida ceifada não incomoda" (EG, 54). Quando o objetivo da vida humana é reduzido a relações de consumo, a busca avassaladora por ter coisas desempenha o papel de fundamento das opções 
profundas (EG, 80), mas, ao mesmo tempo, reduz o próprio ser humano a um bem de consumo que pode ser descartado a qualquer momento (EG, 53 e 195). Francisco realiza uma crítica avassaladora da cultura de consumo como fundamento equivocado da condição humana por expressar um estilo de vida egoísta e individualista, que expressa comodismo, tristeza da frustração e desencanto e um tipo de fuga da realidade da vida. A Teologia da libertação produziu importante literatura sobre esse tema. As palavras do papa podem perfeitamente encontrarem eco nas reflexões, por exemplo, de Jung Mo Sung (2008b, 2005) sobre a concepção da condição humana que se pretende realizada pelo consumo, na obsessão por conquistar o que outros possuem e o desencanto da vida que eleva ao critério de realização máximo a propriedade de coisas. Na encíclica, esta crítica está presente desde a primeira página até as últimas exortações do pontífice.

A redução da vida humana ao consumo é vinculada ao processo de absolutização do mercado. O consumismo leva ao enfraquecimento do compromisso com o mundo e da vontade do encontro com o outro, impondo um estilo de vida oposto à espiritualidade que preconiza "dar a vida pelos outros na missão” (EG, 80). Por sua vez, a busca pela autonomia absoluta dos mercados é denunciada como causa estrutural da desigualdade social (EG, 202). As consequências da absolutização do mercado são, em geral, elementos que já apareceram em documentos de outros papas ou conferências episcopais. No entanto, agora não temos nenhum tipo de elogio ou ressalva positiva. O efeitos são o desequilíbrio e o aumento da desigualdade radical, no qual os lucros de poucos crescem exponencialmente enquanto a maioria está longe do bem-estar; a implacável lógica da dívida e dos juros afastam os países das possibilidades de viabilizarem a sua própria economia; promove a ambição sem limites pelo poder e pelo ter; além de "fagocitar" tudo e qualquer coisa que interesse ao acúmulo, deixando indefesos os mais frágeis, sejam pessoas, comunidades ou mesmo o meio ambiente. Aqui o papa conclama a recusar a lógica estrutural do capitalismo: "Não a um dinheiro que governa em vez. de servir".

A Escola do Dei chamou de ética do sujeito o princípio que coloca a vida humana como critério universal de julgamento. Este critério instaura a verdadeira liberdade cristã que implica o discernimento da lei. Se a vida humana é o critério, a lei deve estar a serviço do humano, não o seu contrário. A vida humana como critério absoluto instaura desdobramentos teológicos. Para Hinkelammert, "esta ética del sujeto es a la vez necesariamente la referencia 
de cualquier discernimiento de los dioses" (2005, p.31)", pois trata-se da absolutização do valor da vida humana frente a qualquer instituição, lei, projeto ou, até mesmo, qualquer "deus". Ainda, segundo Hinkelammert, esta é uma crítica central no sistema em que vivemos, pois ao "divinizarlo, el sistema se fetichiza (...). El ser humano parece condenado a sufrirlo y a someterse. Deja de ser sujeto de su propia vida (HINKELAMMERT, 2005, p.27).

Esse fato, desenvolvido por Marx como fetichização, modifica a consciência do certo e do errado. Absolutizado o sistema de mercados, passa a ser considerado como ato moral tudo o que beneficia o sistema capitalista. Assim a ganância, o individualismo e o consumismo passam a ser considerados fazer o bem e surge uma motivação própria, uma teleologia do capitalismo, uma mística da corporeidade abstrata, derivada da ética do mercado. Na Teologia da libertação, esta relação foi considerada idolatria, sendo a ética do sujeito seu critério de discernimento: Fazer-se livre frente ao sistema absolutizado é ser capaz de defender sempre a possibilidade da vida.

É curioso, mas parece ser o mesmo sentido em que o papa Francisco afirma que a verdadeira ética leva a Deus (não qualquer Deus!) que espera uma resposta comprometida, e que está fora das categorias do mercado: "Deus é incontrolável, não manipulável e até mesmo perigoso, na medida em que chama o ser humano à sua plena realização e à independência de qualquer tipo de escravidão" (EG, 57). Por outro lado, o sistema atual manifesta um desprezo sarcástico com a ética, "considerada contraproducente, demasiado humana, porque relativiza o dinheiro e o poder. É sentida como uma ameaça, porque condena a manipulação e degradação da pessoa" (EG, 57).

Como consequência, o dinheiro relativizado deve servir a vida humana, não o contrário. Quando a idolatria do dinheiro se instaura, inverte-se a relação de modo desumano. Se o dinheiro (com o lucro) passa a ocupar o lugar de critério máximo, decisões que salvam o mercado financeiro, mesmo que imponham sofrimento, piora das condições de vida ou mesmo a morte das pessoas, passam a ser vistos de forma invertida, como eticamente corretas. Precisam ser recusadas e pensadas fora da lógica do mercado.

Esta inversão ética oculta que, de fato, como diz o Papa, a injustiça está na razia do sistema econômico em vigor. Neste sentido, a autonomia absoluta dos mercados e da especulação financeira não são capazes de resolver as causas estruturais da pobreza (EG, 202). Por isto, Francisco aponta a necessidade da "criação de uma nova mentalidade que pense em termos de comunidade, de prioridade da vida de todos sobre a apropriação dos bens 
por parte de alguns" (EG, 188). A disjuntiva é clara. A solidariedade deve se fazer carne, permitindo a mudança das estruturas sociais e da mentalidade que permitam novas convicções e atitudes (EG, 189).

\section{c. Laudato Si}

A encíclica Laudato $S i$ despertou maior atenção da comunidade externa à igreja por colocar como tema central a questão ecológica ${ }^{17}$. Entretanto, o documento apresenta certa continuidade, associando a evangelização com a crítica de uma forma de viver sob este sistema social. A denuncia central de um sistema econômico que gera ao mesmo tempo crise social e crise ambiental também foi esboçada na encíclica anterior (ex. EG, 215-216). Os poderes econômicos ignoram a degradação ambiental e a degradação humana e ética que promovem ao colocar como objetivo central a especulação e o lucro (LS, 56). As relações que tradicionalmente a Teologia da libertação chamou de fetichismo e reificação aqui surgem explicitadas como uma patologia do "relativismo prático", em que prevalece um estilo de vida desordenado, em que tornar as pessoas como coisas e as coisas como absolutas são lógicas que se alimentam mutuamente (LS, 122).

Esta patologia encontra-se impregnada na cultura e é relativista por questionar quaisquer princípios que possam ser universalmente válidos que permitam questionar os mecanismos do mercado. Desse modo, nem a ação política nem o direito são suficientes para superar um sistema de exploração de um ser humano sobre o outro, que "impele uma pessoa a aproveitar-se de outra e a tratá-la como mero objeto" (LS, 123).

Esta lógica, como fundamento cultural, é a mesma que permite que haja vários tipos de violências como os trabalhos forçados, pessoas reduzidas à escravidão por dívida, a exploração sexual das crianças, o abandono dos idosos como descartáveis. Mas não apenas vitima os indivíduos, como atinge proporções sobre toda a sociedade ao instituir um "desejo desordenado de consumir mais do que realmente se tem necessidade", levando a sempre mais usar e jogar fora, no descarte cotidiano que escalona a produção de resíduos. Também expressa sua lógica interna ao nível econômico e social ao propor: "Deixemos que as forças invisíveis do mercado regulem a economia, porque os seus efeitos sobre a sociedade e a natureza são danos inevitáveis" (LS, 123, destaque nosso).

\footnotetext{
17 Veja LÖWY, 2017.
} 
Neste documento, Francisco afirma que a economia não está a serviço da vida. Contrapõe um domínio absoluto da finança com o futuro (LS, 189), uma concepção mágica do mercado, na qual o lucro resolve tudo (LS, 190). No entanto, o princípio da maximização do lucro é uma distorção da economia (LS, 195), que não permite salvar nem os pobres nem o meio ambiente. Tal princípio se preocupa em salvar bancos, fazendo a população pagar o preço (LS, 189). Quem está “obcecado com a maximização dos lucros” não é capaz de raciocinar na lógica necessária para compreender os ritmos da natureza, seus tempos de regeneração e a complexidade dos ecossistemas. No cálculo do lucro, não se considera seriamente o valor das coisas e seu real significado para as pessoas, as culturas e, em especial, os pobres. Compreende a natureza como um reservatório que está disponível para potencializar o acúmulo financeiro e pouco interessa se o resultado imediato tem impacto ambiental ou social (LS, 195). O papa sentencia que o mecanismo do mercado não é apto para defender ou promover a defesa da vida (LS, 190).

A crise econômica deveria ter levado a um novo modelo, mas não fez pela incapacidade desta lógica em pensar fora do princípio do lucro. A alternativa somente é possível associando um outro estilo de vida, uma educação para novos hábitos que integrem o humano e o ecológico e, ainda, a conversão ecológica para a sobriedade. O outro estilo de vida deve negar a proposta antropológica do mercado, que propõe a liberdade pelo consumo enquanto impõe um mecanismo consumista compulsivo e obsessivo (LS, 203). A educação proposta deve indicar outro sentido para a vida, renunciando ao que o mercado oferece. Não basta ter consciência ecológica e lutar pela defesa do meio ambiente sem romper com a mera acumulação de objetos e prazeres e cos mitos da modernidade (individualismo, progresso ilimitado, concorrência, consumismo, mercado sem regras) e do progresso atual (LS, 209-210). Hoje, os "mecanismos eficazes do mercado" ensinam um modelo de ser humano e de vida em sociedade que precisa ser superado em um itinerário pedagógico da solidariedade, da responsabilidade, do cuidado e da compaixão (LS, 215, 210). Por fim, a conversão à sobriedade não é mera modificação de hábitos, mas a transformação dos desejos fundantes, podemos assim dizer, por incluir a experiência de ruptura com o desejo consumista entorpecente que tende ao infinito, sempre insatisfeito e exigindo ansiosamente mais posse de bens e prazeres, para encontrar um modo de ser feliz experimentando dar apreço a cada pessoa e alegrar-se com a simplicidade. Seria recolocar as coisas em seu lugar. 
Como indicamos no comentário à EG, a temática do desejo pelo consumo e a absolutização do mercado estão no centro de uma parte da Teologia da libertação. Aqui vale acrescentar que o tema educação para outro sentido de vida e a conversão dos desejos está presente na obra de Jung Mo Sung $(2007,2008)$. Ainda, não podemos deixar de comentar uma passagem da LS afirma que "não podemos defender uma espiritualidade que esqueça Deus todo-poderoso e criador. Neste caso, acabaríamos por adorar outros poderes do mundo..." (LS, 75). Este não é justamente o fundamento da crítica à idolatria?

\section{d. Amore Letitiae e Gaudate et exultate}

A Encíclica Amore Letitiae é resultado do sínodo sobre a família e não trata diretamente do tema da idolatria. O documento provocou diversos questionamentos dos setores conservadores da própria Igreja Católica ao deslocar o discernimento da doutrina cristã para a vida concreta das pessoas. Parece apropriado entender essa encíclica como uma aproximação da categoria da liberdade cristã, em que a vida prevalece sobre a lei, mesmo a lei religiosa. No entanto, não se trata de ruptura em relação aos documentos anteriores: enfatiza a necessidade de que a evangelização "denuncie, com desassombro, os condicionalismos culturais, sociais, políticos e económicos, bem como o espaço excessivo dado à lógica do mercado" (AL, 201), pois considera esta lógica responsável pela geração e desenvolvimento da pobreza, da exclusão, da violência e da discriminação. Tal conjunto impede diretamente uma vida familiar autêntica.

Uma aplicação deste raciocínio associa-se à crítica da sociedade de consumo em que "tudo se destina a ser comprado, possuído ou consumido, incluindo as pessoas" (AL, 127). O processo de reduzir a pessoa a um objeto de consumo é conhecido, como já dissemos antes, pela reificação, que se articula à fetichização das mercadorias que aposta na posse e consumo como fonte de felicidade ao satisfazer os desejos, que aqui são chamados "desejos de posse egoísta". O contraponto efetivo a esta relação é a manifestação do amor e da ternura que libertam desse desejo, permitindo-nos "saborear o carácter sagrado da pessoa, sem a imperiosa necessidade de a possuir" (AL, 127).

Na Encíclica Gaudate et exultate, cujo tema principal é vida de santidade na sociedade, o eixo da crítica ainda está articulado em torno da sociedade de consumo, em sintonia com o magistério anterior de Francisco. É um apelo a superar a dicotomia entre a vida espiritual e a vida humana propriamente 
dita. O papa indica o encontro com o próximo como grande valor do discernimento da vivência espiritual cristã, que se faz solidariedade com os fracos e denúncia das formas de exploração e violência.

Curiosamente, nesse documento há um interessante deslocamento. $\mathrm{O}$ comunismo não é mais apresentado como "ideologia que mutila o coração do evangelho", mas como suspeita sobre quem tem compromisso social (n.101 ou 109). Na prática, trata de responder as diversas acusações de comunismo ou de anticapitalismo direcionadas à Francisco pelo teor de seu magistério e de sua ação prático-simbólica. De modo coerente, transpõem-se as acusações que décadas atrás se direcionavam aos bispos engajados como Dom Helder Câmara para o bispo de Roma, o papa Francisco. E a defesa do pontífice é, explicitamente, também defesa de toda essa geração de bispos comprometidos e proféticos que foram perseguidos e caluniados mesmos por seus pares. Agora, pela primeira vez, o comunismo não é citado como grande perigo, mas como um tipo de práxis que se confunde com a práxis dos cristãos.

\section{Considerações}

Nossa proposta neste estudo indica um exercício de verificação da utilização de uma categoria nos documentos do magistério pontifício recente. Claro que a escolha da categoria indica o tipo de conflito que nos interessa: a busca pela categoria da idolatria permite-nos identificar elementos do modo pelo qual um setor da Teologia da libertação, como aquele em diálogo com a Escola do DEI, foi teoricamente combatido pelo papa João Paulo II e, até então, reintegrado pelo papa Francisco. Sobre esta escolha, valem algumas considerações. Primeiro é perceber que parte da própria Teologia da libertação, que não se identifica com o uso da teoria do fetiche para a própria reflexão teológica, estratégica ou convenientemente, fez questão de diferenciar-se do marxismo quando pareceu necessário. Segunda consideração, ligada diretamente a esta, é reconhecer que o combate de João Paulo II à teologia que dialoga com economia, infelizmente, não se limitou a uma discussão teórica, encontrando na figura de Oscar Romero um símbolo importante. A terceira consideração, partindo do simbolismo de Romero, canonizado por Francisco após a indiferença de João Paulo II, é como categorias antes combatidas agora são utilizadas como armas da crítica na defesa das vítimas do neoliberalismo. Portanto, podemos dizer que especificamente a temática da idolatria hoje um importante articulador teológico entre crítica social e pensamento cristão católico. 
Neste sentido, este tipo de conclusão nos parece mais significativo e elucidativo do que as perguntas que formulam sobre a pertença de Bergoglio à qual corrente teológica ou se se trata de uma radicalização comunista. Estas questões permitem pensar mais sobre o contexto da disputa, do que sobre o próprio pensamento do magistério atual.

Claro que estas considerações fazem mais sentido se explicitamos que, como pressuposto, compreendemos que o objetivo da elaboração teológica não é a busca por uma classificação verdadeira, mas pelo discernimento dos sinais dos tempos para evitar que a injustiça vitime os pobres. Este estudo tem limites óbvios, aos quais gostaríamos de indicar duas perspectivas que precisam ser melhor estudadas, em seu potencial de convite à transformação das vidas humanas: um aspecto é a simbologia do pontificado de Francisco, incluindo desde sua primeira referência frente ao povo na Praça do Vaticano, até suas canonizações e visitas cotidianas. O outro aspecto, são os temas globais de seu papado, destacando a necessidade de aprofundar certos discursos como aos movimentos sociais na Bolívia, mas também algumas cartas a determinados movimentos eclesiais e congregações. O conjunto dos elementos da visão de mundo de Francisco parecem indicar a urgência da conversão pessoal e comunitária, na recusa radical dos valores do fetichismo, como a meritocracia, a ganância e a negação da dignidade humana a quem é mais fraco. Tudo indica que a articulação entre idolatria e fetiche neste período de acirramento do ódio, da exploração e precarização do trabalho e da exaltação da violência como forma política, as contribuições da Teologia da libertação são imprescindíveis. Precisam ser renovadas não apenas como estudos, mas como instrumento de desvelamento da dominação e da des-humanização.

\section{Referências}

ASSMANN, H.; HINKELAmMERT, F. A idolatria do mercado. Petrópolis: Vozes, 1989.

BENTO, F. R. Adeus reformismo. Papa Francisco e a Doutrina Social da Igreja. Perspectiva Teológica, Belo Horizonte, v. 50, n. 3, p. 509-523, Set./Dez. 2018.

BEOZZO, J.O. Pacto das Catacumbas. São Paulo: Paulinas, 2015.

CARRANZA, B. Papa Francisco: continuidades essenciais e rupturas simbólicas. IHU On-Line (UNISINOS. Impresso), v. 465, p. 135-136, 2015.

COELHO, A. S. Ensino Social da CNBB: crítica ao capitalismo neoliberal e ilusão transcendental (2006) Dissertação de Mestrado. UMESP, S. B. do Campo, SP.

COELHO, A. S. Capitalismo como Religião: uma crítica a seus fundamentos míticoteológicos (2014). Tese de doutorado. UMESP, São Bernardo do Campo, SP. 
COELHO, A. S. Legitimação teológica do sofrimento como pedagogia: crítica em Veena Das. Educação. Vol. 40 (1), 2017.

COELHO, A. S. Entre acusações e perplexidades: o anticapitalismo e o Papa Francisco. Revista Caminhos-Revista de Ciências da Religião. Vol.16 (1), p.63-81, 2018.

DUSSEL, E. Para uma Ética da Libertação Latino-Americana: Uma Filosofia da religião Antifetichista. São Paulo: Loyola/Piracicaba: Editora UNIMEP, volume V, 1977.

DUSSEL, E. Ética Comunitária. 3.ed. Petrópolis: Vozes, 1994.

DUSSEL, E. Ética da libertação: na idade da globalização e da exclusão. Petrópolis: 4.ed. Vozes, 2012.

FAGGIOLLI, M. Roma de quem? Burke, Bannon e a Cidade Eterna. Commonweal, 18/10/2018. Traduzido por IHU e disponível em http://www.ihu.unisinos.br/188-noticias/ noticias-2018/583877-burke-bannon-e-a-cidade-eterna-artigo-de-massimo-faggioli. Acesso em 20/10/2018.

FRANCISCO. Lumem fidei (LF). São Paulo: Paulus, 2013.

FRANCISCO. Exortação Apostólica Evangelii Gaudium (EG). São Paulo: Loyola, 2014.

FRANCISCO. Carta Encíclica Laudato Si’ (LS). São Paulo: Paulus/Loyola, 2015.

FRANCISCO. Exortação Apostólica Pós-sinodal Amoris Laetitia (AL). São Paulo: PaulusLoyola, 2016.

FRANCISCO. Exortação Apostólica Gaudete et Exultate (GE). Disponível em http:// w2.vatican.va/content/francesco/pt/apost_exhortations/documents/papa-francesco_ esortazione-ap_20180319_gaudete-et-exsultate.html acesso 12/04/2018.

GOLDMANN, L. Le Dieu Caché. Paris: PUF, 1959.

HINKELAMMERT, F. As armas ideológicas da morte, São Paulo: Paulinas, 1983.

HINKELAMMERT, F. Prometeo: discernimiento de los deuses y la ética del sujeto. Utopía y Praxis Latinoamericana, Maracaibo: Univ. del Zulia, out/dez 2005, vol.10, n.31, p.09-36.

JOÃO PAULO II. Carta Encíclica Sollicitudo rei socialis (SRS). São Paulo: Paulinas, 1988.

JOÃO PAULO II. Centesimus annus (CA). São Paulo: Paulinas, 1991.

JOÃO PAULO II. Exortação Apostólica Vita consecrata (VC). São Paulo: Loyola, 1996.

JOÃO PAULO II. Ecclesia in america (EA). São Paulo: Paulus, 1999.

LÖWY, M. Redenção e Utopia. São Paulo: Companhia das Letras, 1989.

LÖWY, M. Romantismo e messianismo: ensaios sobre Lukács e Walter Benjamin. São Paulo: Perspectiva, 1990.

LÖWY, M. Marxismo e Teologia da Libertação. São Paulo: Cortez, 1991.

LÖWY, M. "Messianismo e Revolução". in: NOVAES.A.(org). A crise da razão. São Paulo: Companhia das Letras, 1996.

LÖWY, M. "La idolatría del mercado. La crítica del fetichismo capitalista de Marx a la Teología de la Liberación". Revista Pasos, San José: DEI, nov/dez 1999, n.86.

LÖWY, M. A Guerra dos Deuses: Religião e Política na América Latina. Petrópolis: Vozes/ CLACSO, 2000. 
LÖWY, M. Walter Benjamin: aviso de incêndio. São Paulo: Boitempo, 2005.

LÖWY, M. Lucien Goldmann: marxiste pascalien. (2011), disponível em http://www.editionsharmattan.fr/index.asp? navig $=$ catalogue\&obj $=$ article\&no $=22180$

LÖWY, M. O que é Cristianismo de Libertação: religião e política na América Latina. São LÖWY, M. Laudato Sí: Uma encíclica antissistêmica. In: LÖWY, M; BENSAÏD, D. Centelhas: marxismo e revolução no século XXI. São Paulo: Boitempo, 2017.

LÖWY, M.; NAÏR, S. Lucien Goldmann ou a dialética da totalidade. S. Paulo: Boitempo, 2008. MANZATTO, A. O Papa Francisco e a Teologia da Libertação. Revista de Cultura Teológica. Ano XXIII, n.86, jul-dez/2015, p.183-203.

MNDH.[Movimento Nacional de Direitos Humanos]. Roma Locuta. Petrópolis: Vozes, s/d. NADEAU, Barbie Latza. Complô para derrubar o Papa. Daily Beast, 20-06-2018. Traduzido por IHU e disponível em http://www.ihu.unisinos.br/78-noticias/580128-steve-bannon-cardealburke-ministro-salvini-e-o-complo-para-derrubar-o-papa-francisco Acesso em 20/10/2018.

National Catholic Reporter, Editorial, 23/04/2019, [tradução de Moisés Sbardelotto]. "Movimento anti-Francisco liderado por Bannon ameaça a unidade da Igreja". Disponível em http://www.ihu.unisinos.br/588564-movimento-anti-francisco-liderado-por-bannon-ameaca-aunidade-da-igreja Acesso em 24/04/2019.

PASSOS, J. D. Os grandes temas do pontificado do Papa Francisco. Vida Pastoral, julhoagosto de 2017, disponível em http://www.vidapastoral.com.br/edicao/os-grandes-temas-dopontificado-do-papa-francisco/

RICHARD, P. et al. A luta dos deuses. São Paulo: Paulinas, 1982.

SOFIATI, F.M.; CAMILO, R. A. L., COELHO, A. S. Afinidades entre marxismo e cristianismo da libertação. Trans/Form/Ação, Marília, v. 41, n. 4, p. 115-134, Out./Dez., 2018.

STEFANONI, P. Francisco: o papa anticapitalista. Revista IHU Online, 25/07/2015, acesso em 31/03/2018. Disponível em http://www.ihu.unisinos.br/169-noticias/noticias-2015/544870francisco-o-papa-anticapitalista

SUNG, J. M. Idolatria: uma chave de leitura da economia contemporânea? In: BRITO, E. J. C.; GORGULHO, G. (org.). Religião ano 2000. São Paulo: Loyola/PUC-SP, 1998.

SUNG, J. M. Desejo, mercado e religião. Petrópolis: Vozes, 2a . Ed., 1998(b).

SUNG, J. M. Sementes de Esperança: fé cristã em mundo em crise. Petrópolis: Vozes, 2005.

SUNG, J. M. Educar para reencantar a vida. Petrópolis: Vozes, $2^{\mathrm{a}}$ ed., 2007.

SUNG, J. M. Cristianismo de Libertação. São Paulo: Paulus, 2008.

SUNG, J. M. Lutero, a crítica da idolatria do dinheiro e a dialética do possível. Estudos de Religião, v. 30, n. 2, maio-agosto, 2016, p.21-39.

Submetido em: 12-2-2019

Aceito em: 28-4-2019 